\title{
The Problems and Countermeasures of Trade between Russia and Heilongjiang Province
}

\author{
Dandan Qi \\ Institute of Business \& Economic Research , \\ Harbin University of Commerce, Harbin, Heilongjiang Province, China 150028 \\ qidandan77777@126.com
}

Keywords: Sino-Russian trade; Heilongjiang Province; Opportunities; Challenges; Trade complementarity.

\begin{abstract}
China and Russia are the world's two largest neighbors, both countries are in transition phase, although the path is different, but in the economic, trade and scientific and technological cooperation are complementary. China and Russia have highly complementary in the commodity, labor, resources, technology, communications, tourism, industry structure and other aspects. There is an important strategic significance. To strengthen economic and trade cooperation between China and Russia.
\end{abstract}

\section{History and Current Situation of Sino-Russian Trade}

According to the relevant literature, Sino-Russian trade can be traced back nearly 400 years ago began in the late Ming and early Qing Dynasty, the twists and turns during the storm continued, but the overall trend is moving forward. The first Sino-Russian border trade occurred in the northeastern region of Heilongjiang without government involvement, which is completely spontaneous behavior. To 1689, China and Russia signed the "Sino-Russian Treaty of Nerchinsk" border trade was formally have government intervention, an official treaty management and related policy support. To the 1830s Aksu region has become the center of Russia's trade with the Qing government. At the end of the Qing Dynasty, Sino-Russian trade had fluctuated Russia implemented restrictions on foreign imports of goods policy in 1910, and blockaded Vladivostok. After World War I, the Northern government closed the port of China and Russia, the Sino-Russian border trade is basically at a standstill. In the 70's, China has carried out reform and opening up.In 90 years after the liberalization of Russia's implementation of foreign trade between China and Russia were recognized under the economic globalization.In-depth development of bilateral trade to promote regional economic development and social stability has great significance. So far, SinoRussian trade has entered a new stage of development.

After the Cold War, re-division of the world situation is conducive to good relations between the two countries. Two countries issued a regional development plan, China revitalize the old northeast industrial base development strategy to develop Siberia and the Russian Far East regional economic development strategy to provide more opportunities for the development of Sino-Russian trade. A lot of favorable factors in the development of bilateral trade, these factors will provide a strong impetus for the development of bilateral trade. October 2004, the two governments signed in Beijing a new border agreement, determine the long boundary line between China and Russia towards. The agreement lays the foundation for bilateral cooperation to a higher realm. Over the years the two sides to explore the development of both sides of the trade. Such as border trade, processing trade, tourism, trade, barter trade, entrepot trade and so on.

In recent years, from a structural point of view of trade, Russia's resource-intensive products and China's labor-intensive products has a strong complementary. China's land area compared to the wide wrap, rich in natural resources in Russia in terms of plaque relative lack of natural resources, but China is very rich in labor resources, the two countries are highly complementary. Since the Soviet collapse, Russia's military exports to China has been dominated by a large share of the SinoRussian trade share, including fighter jets, submarines, warships, air defense systems and related 
technologies. In recent years, the proportion of exports of natural gas and Russia to build oil pipeline, oil and gas to China is gradually expanding. Russia is s a big country in nuclear industry, it is also strong output power to China. Electronic products made in China has low cost and high quality, which is also very popular in Russia. Sino-Russian trade structure between the two countries are closely related to the level of industrial development and industrial structure, import and export goods in the structure continues to reflect the complementary advantages.

Heilongjiang, Inner Mongolia, Jilin and Xinjiang four provinces border with Russia, where Jilin and Xinjiang border trade volume with Russia is very small, but the volume of trade with Russia, Heilongjiang and Inner Mongolia accounted for the vast majority of our trade with Russia. In particular, Heilongjiang Province, since ancient times and its more frequent contacts in all aspects, Heilongjiang Province and Russia has more than three thousand kilometers of border line, including border river two thousand three hundred hundred kilometers, land and sea transportation is very convenient. Advantages of Heilongjiang Province and Russia distance trade advantages, natural resources, historical experience, cultural knowledge, and other relevant policies. According to "Heilongjiang Statistical Yearbook" in recent years can be seen in the policies and efforts of all parties to promote, the Heilongjiang Russia exports mainly clothing, footwear, textiles, auto parts, plastic products, rice, fruits, vegetables; from Russia imported goods are mainly wood, pulp, sawn timber, fertilizer, scrap, scrap wood. Heilongjiang Province and Russia have built a class of treaty ports in 25 countries. Only 20 kilometers from the Russian coast Suifenhe nearest city. These ports promote understanding and exchanges between China and Russia. Geographically, the Heilongjiang province is blessed with trade with Russia "bridgehead".

During the Eleventh Five, Harbin City seized the Russian accession to the WTO and other opportunity to develop into a national economy and trade in the first district. Efforts to promote the "channel", "three centers", "three platforms" construction. "Channel" means the international air cargo passage. "Three centers" means staple products trading center in Russia, the Russian export processing and distribution center, China-Russia economic and trade cooperation and exchange center. "Three platforms" for the international trade exhibition platform between China and Russia, and Russia and China-Russia financial information platform for e-commerce service platform. In addition, China and Russia also want to build e-commerce network platform to promote business between China and Russia to conduct online transactions. In short, the development of SinoRussian border trade is conducive to northeast border region's economic development in China.

\section{Problems Existing in Sino Russian Trade}

After the Soviet Union collapsed, Russia's domestic politics for so long is not stable enough, the central management of the local government is not enough, the local government for their own consideration even with the central government to develop laws and policies contrary to the policy. Meanwhile, the Russian economic and trade management system has long had corruption problems. Russia's domestic trade policy instability, arbitrary large. April 2004, Russian customs administration suddenly announced strict Chinese imports, the Russian customs tax increase for imported Chinese goods. This makes Chinese exports increased product cost Russia's declining competitiveness. The use of illegal means to handle customs clearance of goods, also known as "gray customs clearance." So that Sino-Russian trade has been affected to a certain extent.

The Sino-Russian border trade exists only in China and Russia is not similar to the trade. Border trade in Russia's foreign trade share is minimal, the Russian government's border trade with China may not have been considered a resort. In recent years, although the Russian government's attitudes have changed, but in general, the emphasis on border trade is still far better than China. Clearance facilities in Russia behind the lower border ports, transport, border quarantine service efficiency. In addition, Russia is much higher than China's port charges, and the Chinese side for immigration control officers more stringent, complex procedures, so that people and goods exit slower. With the development of Sino-Russian trade, dollar settlement currency system to some extent hindered the development of bilateral trade. Mainly in the ruble's exchange rate instability, both sides want to use local currency settlement, you can only set the dollar count. The risk borne by banks in the sale 
process is relatively large. In addition, at the border of the Russian bank size is generally small, low level of credit, the bank is difficult to cooperate with China to develop new settlement products. Since the settlement currency imbalance, the Chinese bargaining power is weak, and local currency settlement more difficult. In recent years, through the joint efforts of both sides, this problem has been overcome to some extent. In 2014, the two sides began the trial RMB settlement directly with the ruble on some trade, which is the development of Sino-Russian trade has played a stimulating effect. Although difficult to implement, but both sides are trying to overcome the difficulties.

Our companies engaged in border trade in larger quantities, but most are small and medium enterprises, the overall strength of the weak, a single mode of operation. Most companies do not produce their own competitive products, but rather a pure trade practices, Heilongjiang-industry trade mainly to the south by means of the product, is more of the production of goods sold to other provinces in Russia, these credit business loans low level, it is difficult from the bank loans, longterm development of enterprises at a disadvantage.

Although since 1996, on the implementation of preferential tax policies, but there is the phenomenon of tax fraud in the actual operation. So that companies can not enjoy the benefits brought about by the halving of VAT, but also increase the tax burden on businesses. Resulting in a sharp drop in corporate profits engaged in border trade. China's trade structure of a single, lower level, restricting trade with Russia has a drawback. In 2011, for example, Heilongjiang Province, "While exports to Russia amounted to more than 2,500 types of goods, electronic products, hightech exports to maintain growth, the quality has been greatly improved. Clothing, footwear, textile exports continue to maintain a major share, accounting ratio of more than 50\%; auto recovery exports, export volume amounted to 2185; agricultural export vegetables, fruits, grain and other exports to China amounted to 480,000 tons in Russia, basically some of the light industrial products, textiles, food. high value-added products of small proportion, but with the recent escalation of Sino-Russian cooperation and strengthening, further consolidate the dominant position in Heilongjiang Province and Russia trade. despite some achievements, but generally speaking, China's northeast Southern areas of goods and products with similar properties to the lack of local characteristics of goods, so the industrial structure will continue to innovation.

\section{Suggestions on Promoting the Development of Sino Russian Trade}

China and Russia should grasp the market changes, optimize the trade structure, according to market demand expand high-level trade and expand the proportion of deep processing of export products. The relatively low level of bilateral trade between China and Russia, can not meet the requirements of economic development of both sides. China to develop technical content, more high-end trade, border trade can not be limited to trade. My Government will continue to develop and improve various preferential policies in trade with Russia, Russia's business environment continues to improve, and give support to disadvantaged businesses, solid market trade. Under policy conditions allowed, we can use the active participation of domestic mature technology in Russia's domestic economic development, development of related technology and equipment export output. In order to obtain greater profits, we must strive to improve the value-added products that increase upgrading the technological content of products. On economic and trade structures, primarily under a variety of industries, such as machinery and electronic products under the premise, accelerate the development of high-tech industries, expand bilateral cooperation platforms, exchanges between the two countries, and promote economic and trade development.

In trade with Russia, the less will affect the normal trade channels running trade with Russia. Therefore, expanding trade channels became problem to be solved, China should increase investment in transport infrastructure, improving traffic environment, enhancing port and road and railway construction, and further widen the channels of trade. Quickly improving the RMB and the ruble currency settlement mechanism to speed up the process of the RMB as an international currency, promote bilateral denominated in RMB. To increase the delivery rate of bank loans, to further accelerate the flow of capital. Both governments want to intervene to establish a risk fund institution for both the bank guarantee. 
To further strengthen the port information management mode, to create information-sharing platform. China and Russia to build e-commerce trading platform. Sino-Russian Suifenhe City, ecommerce platform by the Ministry of Commerce jointly build and second-party e-commerce trading platform, through the integration of Internet information, for Chinese enterprises to build a Russian-through radiation Northeast Asia market as a bridge. Buyers and sellers on the platform supply and demand information release, sent executives to discuss online, translation, generate contracts through the platform, and provides electronic payment, logistics and tracking, and other services, and eventually to complete the transaction.

In the new phase of the Sino-Russian border trade, product quality is the key to capture the market, should establish the concept of quality. Early Sino-Russian border is open, some unscrupulous traders of the counterfeit goods sold abroad, gave economic and trade cooperation has brought great harm, for this country to improve the quality system, but also pay attention to the characteristics of exports. We must seize the Russian market demand continues to adjust and optimize the structure of export commodities, quality assurance, full use of high technology to enhance product design. To create influential brand, there is no brand, you can not fully realize the value of goods, competition in similar products, it is easy at a disadvantage.

Our business must go abroad to choose small projects in Russia and Russia has not yet been developed, such as minerals and timber resources development cooperation projects related to people's lives with light industry, food processing, clothing, textiles, and other projects and infrastructure and environmental protection and other fields. Accelerate the process of economic integration in Northeast Asia, to create a border free trade zones to attract foreign investment, the development of national economy, promoting economic integration in Northeast Asia. To improve the Northeast products in the Russian market competitiveness.

We should vigorously develop the type of talents lacking in the market, vigorously train to master economic knowledge and knowledge of foreign languages class talent, the lack of human resources to improve the market status quo. Russian foreign trade plays an important role in foreign trade activities. Russian foreign trade is not a simple conversion between different languages, but requires the use of a comprehensive knowledge of all aspects, to meet the nation's language habits, truthfully express content. Russian translation in the presence of a problem in the application of trade between China and Russia. Theory and Practice of a certain distance. No practical ability, just put some words mechanically pieced together, it will not logical, so you can not exactly do the work of Russian foreign trade. Russian foreign trade professional culture should define their high-quality talents, to develop students' practical ability, students must have a strong ability of practical application to open an international commercial law, documentation and customs clearance, international trade practices and other foreign trade courses to students practice has been tempered, increased knowledge, the ability to cultivate.

\section{References}

[1] Feng Shaolei, Xiang Lanxin.Russia's Relations With The Great Powers and The Surrounding[M].Shanghai: Shanghai People's Publishing House.2005.

[2] Liu Yanchun,Li Zhankui.Reflections on Strengthening The Trade With Russia in Heilongjiang Province[J]. Siberian Studies.2009(6).

[3] CPC Heilongjiang Provincial Party School Research Group. Heilongjiang's Trade With Russia in 21st Century[J]. Economic Research Reference.1998(42).

[4] Liu Shitao, Wang Qian. Analysis on Sino-Russian Trade[J].Heilongjiang Foreign Trade.2006(4).

[5] Kong Xiangshun. Trend Research in Heilongjiang Province border trade post-crisis period.Heilongjiang Foreign Trade.2011(6).

[6] Yang yang. Study On the Development of Sino-Russian Trade Problems and Countermeasures [J]. Business Research. 2010 (11). 
[7] Russia's main export products to China. National trade reports[R]. 2010.10.

[8] Lang Yu. Trade Development of Heilongjiang Province and Russia in the new situation[J]. Northeast Asia Forum. 2005 (4). 